\title{
INVESTIGATION OF THE REACTION OF PHENYLISOCYANATE WITH N-SUBSTITUTED 2-IMINOOXAZOLIDINES
}

\author{
J.J.Bosc, C.Jarry*, Laboratoire de Chimie physique \\ Universite de Bordeaux II, 33076 Bordeaux cedex, France
}

\begin{abstract}
The reaction of phenylisocyanate with 5-(1-aryl-4-piperazinyl)-2-phenylcarbamoyl-2-iminooxazolidines and with 5-(1-aryl-4-piperazinyl)-2,3-diphenylcarbamoyl-2-iminooxazolidines leads to the 3-phenyl-7-(1-aryl-4-piperazinyl)2,3,6,7-tetrahydro-oxazolo[3,2-a]-1,3,5-triazin-2,4-diones. In one case the reaction could progress via the formation of the corresponding isomeric $\mathrm{N}, \mathrm{N}$-diphenylcarbamoyl-2-amino-2-oxazoline.
\end{abstract}

\section{Introduction}

Like bicyclic 1,3,5-triazin-2,4-diones are described as potential 5-HT2 antagonists related to ketanserin, different methods have been developed for their preparation $(1,2)$. One involves a cyclocondensation reaction from an aminoheterocyclic compound (3-5).

Investigating in details the reaction of 2-amino-2-oxazolines with isocyanates, we described in a previous work the synthesis and the structural assessment of 3-phenylcarbamoyl- and 2,3-diphenylcarbamoyl-2-iminooxazolidines 2 (6). Whereas the 3-phenylcarbamoyl-2-iminooxazolidines rearrange rapidely to their isomeric 2-phenylcarbamoyl-2iminooxazolidines 1, we noticed the stability of the 2,3-diphenylcarbamoyl-2-iminooxazolidines permitting to use them as a reagent. In this work we report the synthesis of the 3-phenyl-7-(1-aryl-4-piperazinyl)-2,3,6,7-tetrahydrooxazolo[3,2-a]1,3,5-triazin-2,4-diones $4(a, b)$ using the reaction of phenylisocyanate with the corresponding 2-phenylcarbamoyl- 1 or 2,3-diphenylcarbamoyl-2-iminooxazolidines 2. By heating, we observed the irreversible rearrangement of 2 to the isomeric $\mathrm{N}, \mathrm{N}$-diphenylcarbamoyl-2-amino-2-oxazolines 3 . These compounds have been isolated as possible intermediates. They conducted to the bicyclic compounds 4 by heating with phenylisocyanate.

\section{Results and discussion}

The reaction of two equivalents of phenylisocyanate with the 2-phenylcarbamoyl-2-iminooxazolidines $1(a, b)$ requires the heating of the two products in xylene during 24 hours (Scheme 1). N,N'-diphenylurea 5 and the 3-phenyl2,3,6,7-tetrahydrooxazolo[3,2-a]-1,3,5-triazin-2,4-diones $4(a, b)$ are obtained with a slight yield. Starting from 2,3diphenylcarbamoyl-2-iminooxazolidines $2(a, b)$, by heating with one equivalent of phenylisocyanate in xylene during 6 hours, we isolated the corresponding 4 with good yields. N,N'-diphenylurea was obtained in parallel with 4.

In order to investigate the mechanism of the reaction, we heated $\mathbf{2}(\mathbf{a}, \mathbf{b})$ quickly up to their melting point. We observed that they rearranged to the corresponding $N, N$-diphenylcarbamoyl-2-amino-2-oxazolines $3(a, b)$. Then $3(a, b)$ have been converted quantitatively to 4 by heating with one equivalent of phenylisocyanate in xylene during 3 hours. 
However, we were unable to isolate 3 during the reaction of $1(a, b)$ with phenylisocyanate. The formation of the $N, N$ 'diphenylurea 5 could be related to a secondary reaction involving the isocyanate (7). Starting from the 5-[(4-phenyl-1piperazinyI)methyl]-2,3-diisopropylcarbamoyl-2-iminooxazolidine (6), by heating with one equivalent of phenylisocyanate in xylene during 6 hours, we isolated $4 a$ with the $N, N^{\prime}$-diisopropylurea. These results suggested that all reactions could pass through a common intermediate state, which was already noticed as the highly instable heterocyclic isocyanate $(8,9)$. Then the triazine ring was formed through an 1,4 addition involving the phenylisocyanate (10).

Scheme 1:<smiles>[R]CC1CNC(=NOCCC)O1</smiles>

$1(\mathbf{a}, \mathbf{b})$

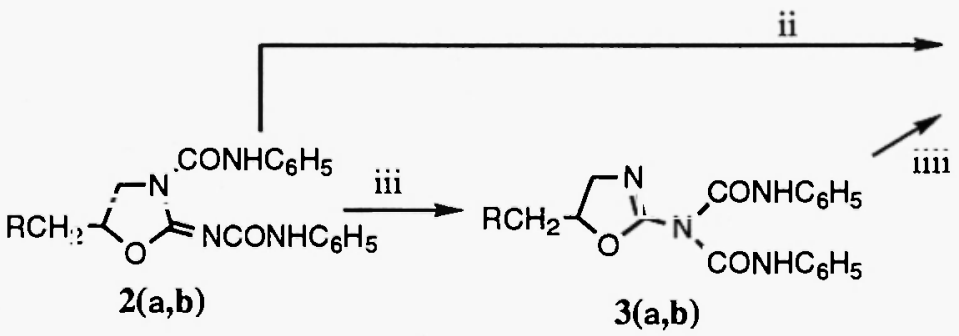

a : $R=$ (1-phenyl-4-piperazinyl)

b : $R=[1-(4-$ methyl)phenyl-4-(3-methyl)piperazinyl $]$

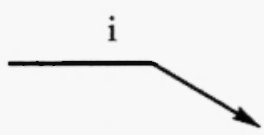

ii

i : $2 \Phi \mathrm{NCO}, 130^{\circ} \mathrm{C}, 24 \mathrm{H}$

ii : $1 \Phi N C O, 130^{\circ} \mathrm{C}, 6 \mathrm{H}$

iii : $\Delta$, neat

iiii : $1 \Phi N C O, 130^{\circ} \mathrm{C}, 3 \mathrm{H}$

Structural elucidation of $3 a$ was accomplished on the basis of spectral data and of microanalyses. The ir spectrum closely resembles the reported spectra of 2-amino-2-oxazolines locked in the amino form by alkyl groups (11). The two $\mathrm{C}=\mathrm{O}$ are quite identical and appear as a single band near $1730 \mathrm{~cm}^{-1}$. The ${ }^{1} \mathrm{H}$ spectrum obtained at $500 \mathrm{Mhz}$ shows two sharp singlets at 9.93 and $9.90 \mathrm{ppm}$ assigned to the $\mathrm{NH}$ protons. For the 2,3-diphenylcarbamoyl-2-iminooxazolidine $2 \mathrm{a}$ we reported the ${ }^{1} \mathrm{H} \delta$ of the two $\mathrm{NH}$ protons at 10.76 and $7.4 \mathrm{ppm}(6)$. In $3 \mathrm{a}$, the protons on the $\mathrm{C}(4)$ and $\mathrm{C}(5)$ positions in the oxazoline ring and the $\mathrm{CH}_{2}$ protons of the lateral chain form an $\mathrm{ABXMN}$ system. The $\mathrm{C}(5)$ methine proton is found at about $4.56 \mathrm{ppm}$ and the $\mathrm{C}(4) \mathrm{H}_{2}$ protons appear as two $\mathrm{dd}$ at 4.14 and $3.97 \mathrm{ppm}$. The ${ }^{13} \mathrm{C} \mathrm{nmr}$ spectrum confirms the 2amino-2-oxazoline structure. The most deshielded signal (155.51 ppm) is assigned to the $C(2)$ carbon of the heterocycle, $a^{3} \mathrm{~J}$ coupling was found between the $\mathrm{C}(2)$ and the $\mathrm{C}(4)-\mathrm{H}$ protons $\left({ }^{3} \mathrm{~J}=2.3 \mathrm{~Hz}\right)$. Because of the symmetry of the two substituents on the exo nitrogen atom, all $\delta$ of the carbon atoms of the two phenylcarbamoyl moieties are quite similar.

The 3-phenyl-2,3,6,7-tetrahydrooxazolo[3,2-a]-1,3,5-triazin-2,4-diones 4 have been characterized by their spectral data. The ir specta of all compounds exhibit two $\mathrm{C}=0$ bands near $1750 \mathrm{~cm}^{-1}$ and $1690 \mathrm{~cm}^{-1}$. For the ${ }^{13} \mathrm{C} \mathrm{nmr}$ spectra , the assignments of the chemical shifts of the $\mathrm{sp}^{2}$-hybridized carbons were partially based on $A b$ initio chemical shifts calculations (5). In the ${ }^{1} \mathrm{H}$ nmr spectra, the $\mathrm{C}(6) \mathrm{H}_{2}$ and $\mathrm{C}(7) \mathrm{H}$ protons on the tetrahydrooxazole ring form a characteristic $\mathrm{ABX}$ system, and all the $\mathrm{NCH}_{2}$ protons appear as a large multiplet.

\section{Experimental}

Microanalyses were carried out at the Service central d'analyse CNRS, Vernaison, France. Melting points were determined with a Kofler hot-stage apparatus and were uncorrected. The ir spectra were obtained with a Bruker IF 25 
spectrophotometer. Nmr data were recorded with a Bruker AC-200 and with a Bruker AMX-500 spectrometers. Chemical shifts ( $\delta$ in ppm) and coupling constants ( $\mathrm{J}$ in Hz) were measured using TMS as internal standard. Silica gel SDS 60 (70230 mesh) was used for column chromatography.

General procedure for the preparation of 5-substituted N,N-diphenylcarbamoyl-2-amino-2-oxazolines 3(a,b)

in a beaker, 0.01 mole of the 5-substituted 2,3-diphenylcarbamoyl-2-iminooxazolidine 2(a,b) was heated quickly up to its melting point with stirring. After cooling the solid was recrystallized from tetrachlorethylene.

5-[(1-phenyl-4-piperazinyl)methyl]- $\mathrm{N}, \mathrm{N}$-diphenylcarbamoyl-2-amino-2-oxazoline (3a)

$\mathrm{mp} \mathrm{:} 223^{\circ} \mathrm{C}$; yield : $90 \%$; ir $(\mathrm{KBr}) \mathrm{cm}^{-1}: 3450,3300(\mathrm{NH}) ; 1730(\mathrm{C}=0) ; 1690(\mathrm{C}=\mathrm{N}) ;{ }^{1} \mathrm{H} \mathrm{nmr} 500 \mathrm{Mhz}\left(\mathrm{CDCl}_{3}\right), \delta \mathrm{ppm}$ :

9.93, $9.90(2 \mathrm{~s}, 2 \mathrm{H}, \mathrm{NH}), 7.19(\mathrm{~m}, 15 \mathrm{H}, \mathrm{Ar}-\mathrm{H}), 4.56(\mathrm{~m}, 1 \mathrm{H}, 5-\mathrm{H}), 4.14,3.97$ (2dd, 2H, 4-H, J=10.9, 9.1, 2.4), 3.19, 2.82, 2.63 (3m, 8H, CH 2 -pip), 2.91, 2.62 (2dd, $\left.2 \mathrm{H}, \mathrm{NCH}_{2}, \mathrm{~J}=12.7,9.1,3.2\right) ;{ }^{13} \mathrm{C}_{\left(\mathrm{CDCl}_{3}\right)} \delta \mathrm{ppm}: 155.2(\mathrm{C}-2), 149.6,149.1$ (CO), 151.1, 137, 129.1, 124.4, 120, 119.9, 119.7, $116\left(C_{\text {Arr }}\right), 76.7(C-5), 59.6,53.9,49.1,44.1\left(\mathrm{NCH}_{2}\right)$.

Anal. Calcd for $\mathrm{C}_{28} \mathrm{H}_{30} \mathrm{~N}_{6} \mathrm{O}_{3}$ : $\mathrm{C}, 67.47 ; \mathrm{H}, 6.02 ; \mathrm{N}, 16.87$. Found : $\mathrm{C}, 67.27 ; \mathrm{H}, 6.08 ; \mathrm{N}, 16.80$.

5-[(1-(4-methyl)phenyl)-4-(3-methyl)piperazinyl)methyl]- $\mathrm{N}, \mathrm{N}$-diphenylcarbamoyl-2-amino-2-oxazoline (3b): $\mathrm{mp}: 224^{\circ} \mathrm{C}$; yield : 83\% ; ir (KBr) cm-1 : 3450, $3300(\mathrm{NH}) ; 1729(\mathrm{C}=0) ; 1710(\mathrm{C}=\mathrm{N}) ;{ }^{1} \mathrm{H} \mathrm{nmr} 200 \mathrm{Mhz}\left(\mathrm{CDCl}_{3}\right), \delta \mathrm{ppm}: 9.93,9.91(2 \mathrm{~s}$, $2 \mathrm{H}, \mathrm{NH}), 7.16(\mathrm{~m}, 14 \mathrm{H}, \mathrm{Ar} \cdot \mathrm{H}), 4.51(\mathrm{~m}, 1 \mathrm{H}, 5-\mathrm{H}), 4.12,3.92(2 \mathrm{~m}, 2 \mathrm{H}, 4-H), 2.81(\mathrm{~m}, 9 \mathrm{H}, \mathrm{NCH} 2), 2.25\left(\mathrm{~s}, 3 \mathrm{H}, \mathrm{CH}_{3}-\mathrm{Ar}\right)$, 0.98 (d, 3H, $\mathrm{CH}_{3}-\mathrm{pip}, \mathrm{J}=6.4$ ) .

Anal. Calcd for $\mathrm{C}_{30} \mathrm{H}_{34} \mathrm{~N}_{6} \mathrm{O}_{3}: \mathrm{C}, 68.44 ; \mathrm{H}, 6.46 ; \mathrm{N}, 15.97$. Found : $\mathrm{C}, 68.39 ; \mathrm{H}, 6.49 ; \mathrm{N}, 15.92$.

General procedures for the preparation of 3-phenvl-7-[(1-aryl-4-piperazinyl])methyl]-2,3,6,7-tetrahydrooxazolo[3,2-a]1.3.5-triazin-2.4-dione (4a.b)

$i$ : 0.02 mole of phenylisocyanate was added dropwise to a heated mixture of 0,01 mole of the 5-substituted 2phenylcarbamoyl-2-iminooxazolidine1 in dry xylene. The mixture was refluxed for 24 hours. After cooling the precipitate formed was collected and crystallized from appropriate solvent (yield in $\mathbf{4}(\mathrm{a}, \mathrm{b})<10 \%$ ).

ii : 0.01 mole of phenylisocyanate was added dropwise to a heated solution of 0,01 mole of the 5 -substituted 2,3diphenylcarbamoyl-2-iminooxazolidine 2 in dry xylene.The solution was refluxed for 6 hours. After cooling the precipitate formed was collected and crystallized from ethanol.

3-phenyl-7-[(1-phenyl-4-piperazinyl)methyl]-2,3,6,7-tetrahydrooxazolo[3,2-a]-1,3,5-triazin-2,4-dione (4a) : $\mathrm{mp}: 283^{\circ} \mathrm{C}$; yield : $53 \%$; ir $(\mathrm{KBr}) \mathrm{cm}^{-1}: 1755,1692(\mathrm{C}=\mathrm{O}) ; 1637(\mathrm{C}=\mathrm{N}) ;{ }^{1} \mathrm{H} \mathrm{nmr} 200 \mathrm{Mhz}\left(\mathrm{DMSO} \mathrm{D}_{6}\right), \delta \mathrm{ppm}: 7.09(\mathrm{~m}, 10 \mathrm{H}, \mathrm{Ar}-\mathrm{H})$, $5.30(\mathrm{~m}, 1 \mathrm{H}, 7-\mathrm{H}), 4.22(\mathrm{t}, 1 \mathrm{H}, 6-\mathrm{H}, \mathrm{J}=9.6,9.3), 3.85(\mathrm{dd}, 1 \mathrm{H}, 6-\mathrm{H}, \mathrm{J}=9.6,7), 3.14,2.88,2.67(3 \mathrm{~m}, 10 \mathrm{H}, \mathrm{NCH} 2) ;{ }^{13} \mathrm{C}$ (DMSO $D_{6}$ ) $\delta$ ppm : $162.7(C-9), 155.5(C-4), 148.3(C-2), 151,135.4,129,128.9,128.7,128.3,118.9,115.4\left(C_{A r}\right)$, $78.8(\mathrm{C}-7), 59.6,53.2,48.3,45.7\left(\mathrm{NCH}_{2}\right)$.

Anal. Calcd for $\mathrm{C}_{22} \mathrm{H}_{23} \mathrm{~N}_{5} \mathrm{O}_{3}: \mathrm{C}, 65.19 ; \mathrm{H}, 5.68 ; \mathrm{N}, 17.28$. Found : $\mathrm{C}, 65.11 ; \mathrm{H}, 5.70 ; \mathrm{N}, 17.26$.

3-phenyl-7-[(1-(4-methyl)phenyl)-4-(3-methyl)piperazinyl)methyl]-2,3,6,7-tetrahydrooxazolo[3,2-al-1,3,5-triazin-2,4dione (4b) : $\mathrm{mp}: 230{ }^{\circ} \mathrm{C}$; yield : 47\% ; ir $(\mathrm{KBr}) \mathrm{cm}^{-1}: 1755,1690(\mathrm{C}=\mathrm{O}) ; 1640(\mathrm{C}=\mathrm{N}) ;{ }^{1} \mathrm{H} \mathrm{nmr} 200 \mathrm{Mhz}\left(\mathrm{CDCl}_{3}\right), \delta \mathrm{ppm}$ : $7.14(\mathrm{~m}, 9 \mathrm{H}, \mathrm{Ar}-\mathrm{H}), 5.15(\mathrm{~m}, 1 \mathrm{H}, 7 \cdot \mathrm{H}), 4.24,4.10(2 \mathrm{dd}, 2 \mathrm{H}, 6-\mathrm{H}, \mathrm{J}=10.2,9.1,6.8), 3.17\left(\mathrm{~m}, 9 \mathrm{H}, \mathrm{NCH}_{2}\right), 2.60\left(\mathrm{~s}, 3 \mathrm{H}, \mathrm{CH}_{3}-\right.$ Ar), 0.97 (d, 3H, $\mathrm{CH}_{3}$-pip, J=6.4).

Anal. Calcd for $\mathrm{C}_{24} \mathrm{H}_{27} \mathrm{~N}_{5} \mathrm{O}_{3}: \mathrm{C}, 66.51 ; \mathrm{H}, 6.24 ; \mathrm{N}, 16.17$. Found : $\mathrm{C}, 66.49 ; \mathrm{H}, 6.26 ; \mathrm{N}, 16.16$

iii : The heating of 0.01 mole of 3 with 0.01 mole of phenylisocyanate in xylene during 3 hours led quantitatively to 4 . 


\section{References}

(1) Y.Wanatabe, H.Usiui, S.Kobayashi, H.Yoshiwara, T.Shibano, T.Tanaka, Y.Morishima, M.Yasuoka and M.Kanao, J.Med.Chem. 35, 189 (1992)

(2) J.L.Herndon, A.Ismaiel, S.P.Ingher, M.Teitler, and R.A.Glennon, J.Med.Chem. 35, 4903 (1992)

(3) A.Kamal and P.B.Sattur, Synthesis 892 (985)

(4) S.Purkayastha and R.P.Panzica, J.Heterocyclic Chem. 27, 743 (1990)

(5) O.Adetchessi, D.Desor, I.Forfar, C.Jarry, J.M.Leger, M.Laguerre and A.Carpy, Heterocycles in press

(6) J.J.Bosc, C.Jarry, M.Laguerre, J.Ouhabi and A.Carpy, Can.J.Chem. in press

(7) D.P.N.Satchell and R.S.Satchell,Chem.Soc.Rev. 4, 231 (1975)

(8) G.Puglisi, R.Pignatello, A.Panico, G.Mazzone, A.Corsaro, A.Caruso, M.G.Leone, M.Amico-Roxas, Eur.J.Med.Chem. 24, 277 (1989)

(9) M.Tisler and B.Stanvnik, J.Chem.Soc. Chem.Comm. 313 (1980)

(10) R.Richter and H.Ulich, Chem.Ber. 103, 3525 (1970)

(11) J.R.Carson, G.I.Poos and H.R.Almond, J.Org.Chem. 30, 2295 (1965)

Received February 20, 1996 